\title{
O ESTILO DE \\ GRACILIANO RAMOS: UMA DESTERRITORIALIZAÇÃO DA LÍNGUA
}

Bruno Henrique Alvarenga Souza*

(iD) https://orcid.org/0000-0001-5005-1883

Como citar este artigo: SOUZA, B. H. A. O estilo de Graciliano Ramos: uma desterritorialização da língua. Todas as Letras - Revista de Língua e Literatura, São Paulo, v. 22, n. 2, p. 1-17, maio/ago. 2020. DOI 10.5935/1980-6914/eLETLT2011800

Submissão: setembro de 2018. Aceite: abril de 2020.

Resumo: Este artigo tem por objetivo analisar o estilo de Graciliano Ramos, explorando, como aspectos constituintes da formação do escritor, a relação estabelecida entre a apreensão da linguagem, o domínio da leitura e o confronto com as linhas de força do processo educacional expostos no livro de memórias Infância.

Palavras-chave: Graciliano Ramos. Estilo. Linguagem. Deleuze. Formação. 


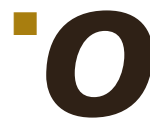

principal aspecto que salta aos olhos do leitor, seja este especializado ou não, no primeiro contato com a literatura de Graciliano Ramos, é o seu estilo. É praticamente unânime na crítica a caracterização da prosa de Graciliano Ramos como magra, direta, gramaticalmente impecável. A figura do escritor que suprimia períodos inteiros, abdicava de adjetivos e tinha horror à prolixidade já habita o imaginário dos estudiosos de literatura no País.

Tal imagem foi delineada por Otto Maria Carpeaux em um dos mais belos textos já publicados sobre o escritor alagoano. Para o crítico, "estilo é escolha entre o que deve perecer e o que deve sobreviver" (CARPEAUX, 1978, p. 25). Para ele, Graciliano

[...] é muito meticuloso. Quer eliminar tudo que não é essencial: as descrições pitorescas, o lugar-comum das frases feitas, a eloquência tendenciosa. Seria capaz de eliminar ainda páginas inteiras, eliminar os seus romances inteiros, eliminar o próprio mundo. Para guardar apenas o que é essencial, isto é, conforme o conceito de Benedetto Croce, o "lírico". O lirismo de Graciliano Ramos, porém, é bem estranho. [...] O lirismo de Graciliano Ramos é amusical, adinâmico, estático, sóbrio, clássico, classicista, traindo às vezes, um oculto passado parnasiano do escritor. Não quer agitar o mundo agitado; quer fixá-lo, estabilizá-lo. Elimina implacavelmente tudo o que não se presta a tal obra de escultor, dissolve-o em ridicularias, para dar lugar aos seus monumentos de baixeza (CARPEAUX, 1978, p. 25).

Esse trecho sintetiza de forma categórica todo o procedimento estilístico de Graciliano Ramos: uma escrita do básico, da recusa à retórica elaborada e enganosa e, acima de tudo, um processo de destruição. Carpeaux (1978, p. 26) cedo notou a espécie de conatus que o ato de suprimir (para usar aqui um verbo caro ao próprio Graciliano) relaciona-se, na obra do escritor alagoano, à busca da "solução de um problema vital".

Para evidenciar essa metodologia destruidora, cabe citar ainda a célebre analogia entre a atividade da escrita e o trabalho das lavadeiras de Alagoas colocada pelo próprio Graciliano:

Deve-se escrever da mesma maneira com que as lavadeiras lá de Alagoas fazem em seu oficio [...]. Elas começam com uma primeira lavada, molham a roupa suja na beira da lagoa ou do riacho, torcem o pano, molham-no novamente, voltam a torcer. Colocam o anil, ensaboam e torcem uma, duas vezes. Depois enxáguam, dão mais uma molhada, agora jogando água com a mão. Batem o pano na laje ou na pedra limpa, e dão mais uma torcida e mais outra, torcem até não pingar do pano uma só gota. Somente depois de feito tudo isso é que elas dependuram a roupa lavada na corda ou no varal, para secar. Pois quem se mete a escrever devia fazer a mesma coisa. A palavra não foi feita para enfeitar, brilhar como ouro falso; a palaura foi feita para dizer (RAMOS, 2014, p. 77).

Escrever é um trabalho de limpeza, de desinfecção. Graciliano quer se afastar de toda bactéria, de toda sujeira, de toda sobra ignominiosa, mesmo que, para erradicar a praga, tenha de queimar toda vestimenta e enfeite, precise extirpar, mais que a gordura, toda a carne da palavra. Escrever é expor o osso que sustenta cada letra, o arcabouço que sustenta as bases de toda frase.

Em um dos episódios do livro memorialista Infância, intitulado "Um enterro", o menino-protagonista fica preso em um ossuário e, em meio às caveiras e 
esqueletos, observa a perecibilidade e "imundície" da carne, fadada ao apodrecimento. Conclui que do corpo "[só] o esqueleto resistiria. Ossos" (RAMOS, 2002, p. 173). Tal como o corpo humano, o corpo da prosa é efêmero e indelével. No fim, só perseveram os ossos, o essencial lírico de que fala Carpeaux: o alicerce, o sustentáculo de toda a sintaxe.

Mais que construir monumentos e lapidar esculturas, Graciliano destrói tudo o que pode, deixando visíveis e legiveis apenas esqueletos, "seus monumentos de baixeza". Assim é seu procedimento estilístico, método útil para se transformar a escrita em máquina de guerra, pois - algo que Graciliano aprendeu cedo - as palavras são como as "sovelas [que] furam e a faca pequena [que] corta. São armas insignificantes, mas são armas" (RAMOS, 2002, p. 184). Eliminar, suprimir, destruir, erradicar até que reste apenas o que não pode deixar de ser dito. A formação dessa espécie de diagrama não é aleatória, mero capricho de escritor, uma escolha de l'art pour l'art. Por trás da magreza de sua sintaxe, avulta uma concepção de mundo muito elaborada, uma espécie de projeto ético-estético que procuraremos explorar ao demonstrar que, avesso a todo excesso, Graciliano é um autor do menos, um autor menor.

Em Kafka: por uma literatura menor (2014), Deleuze e Guattari traçam as diretrizes do que seria uma literatura menor. O primeiro ponto é: nessa literatura, a questão do estilo é primordial; está ligada tanto a um fato de linguagem quanto a um problema de território. Menor aqui não significa inferior: produzir uma literatura menor é desterritorializar a língua maior, minorar o idioma de que o escritor dispõe, retirando-o de seu uso comum e institucionalizado, criando uma espécie de língua estrangeira dentro da própria língua.

Assim fez Kafka, judeu-tcheco escrevendo em alemão, com a língua maior de Goethe: em sua condição de estrangeiro, produziu uma língua que não é nem alemão, nem tcheco, nem iídiche, mas algo completamente diferente, oriundo da poliglossia na qual estava inserido. Mas isso não quer dizer, necessariamente, que a criação deva ser proveniente de um multilinguismo. Fazer literatura menor é trabalhar a linguagem através de uma lógica da sensação. O objetivo, mais que misturar duas ou mais linguas e criar novas palavras, é "fazer a lingua gritar, gaguejar, balbuciar, murmurar em si mesma” (DELEUZE, 2011, p. 141), em suma, dar à língua um uso intensivo, retirá-la da representação, levá-la à percepção pura, à experimentação.

Entendendo a língua como um sistema em desequilíbrio, o escritor menor introduz constantes variações no uso padrão, maior, do idioma. É, antes de tudo, um procedimento político: reverter o uso modelo da língua, fazer implodir a comunicação oficial para devolvê-la ao povo. A língua estranha que surge desse procedimento é o próprio estilo, e ela nada tem nada a ver com casos nacionais "Um grande escritor sempre se encontra como um estrangeiro na lingua em que se exprime, mesmo quando é a sua lingua natal” (DELEUZE, 2011, p. 141).

Em uma carta à esposa, Heloísa, na época da feitura de seu segundo romance, Graciliano afirma que precisaria traduzir o primeiro rascunho de S. Bernardo para o "brasileiro, um brasileiro encrencado, muito diferente da gente da cidade, um brasileiro de matuto" (RAMOS, 1994, p. 135).

Em toda a sua obra, desde os famigerados relatórios enviados ao governador de Alagoas até as últimas páginas das Memórias do cárcere, o que mais fez Graciliano se não desterritorializar o português oficial e remetê-lo a um complexo contexto colonial? Não com intenção de criar uma linguagem nacional, mas, 
assim como o iídiche de Kafka, mesclando-se ao alemão para formar uma nova língua além de qualquer pátria, introduzindo o "brasileiro encrencado de matuto" no cerne do português da metrópole. O que se não isso consiste em encontrar uma língua menor dentro de uma lingua maior?

O procedimento adotado para criar essa língua menor, no entanto, é bastante curioso. Dotado de uma precisão gramatical rigorosa, Graciliano também admirava a linguagem dos caboclos do Nordeste, "que falam bem", e dizia ser essa a região "onde a língua se conserva mais pura" (RAMOS, 2014, p. 55). Considerava tais caboclos, inclusive, depositários de uma sabedoria linguística superior aos "doutores" das grandes cidades: "num caso de sintaxe de regência, por exemplo, entre a linguagem de um doutor e a do caboclo não tenha dúvida, vá pelo caboclo - e não erra" (RAMOS, 2014, p. 55).

Graciliano não é, portanto, um escritor gramatiqueiro, refém das regras da língua culta como muitas vezes é erroneamente considerado; ao contrário, o interesse pela linguagem oral que permeia toda a sua obra é parte constituinte de seu plano estético. Para afastar-se da armadilha da escrita ornamentada, Graciliano aproxima-se da oralidade sertaneja. Esse uso de um português extremamente correto aliado a vocábulos de cunho regionalista deu à literatura de Graciliano uma espécie de dignidade ímpar no contexto das letras brasileiras. Como bem disse um crítico, "ninguém entre nós soube, como Graciliano, manter um tão perfeito equilíbrio entre a sintaxe e o vocabulário corrente no Brasil" (PEREIRA, 1978, p. 156).

Uma tal concepção de prosa não é fruto do acaso, um projeto político a atravessa: como em toda literatura menor, em Graciliano a língua torna-se instrumento de oposição, de resistência à autoridade de mestres, começando, obviamente, pelos mestres canônicos. Talvez por isso as enormes reservas a Machado de Assis, autor "que não será nunca um escritor popular" (RAMOS, 2002, p. 104); a seus "amigos", que cultuam o literato carioca como a um deus; à sua cria, a Academia Brasileira de Letras.

Contra qualquer instituição que porventura venha a sancionar a literatura, Graciliano buscou por meio da escrita dar voz à palavra humilde da escória social na sociedade brasileira. O escritor deve escrever por um povo que falta, não em lugar de, mas em intenção de, sendo esse o fim último da literatura (DELEUZE, 2011 , p. 16). Talvez isso explique sua fixação por tipos como Luís da Silva, protagonista de Angústia, homem miserável e atormentado, que acaba recorrendo ao assassínio quando se vê superado por um burguês; por Fabiano e sua família, retirantes explorados pela autoridade, pelo empregador e até pelo clima; e mesmo por Paulo Honório, homem que consegue ascender socialmente por meio de sua obstinação capitalista, mas acaba se perdendo no processo de enriquecimento.

O material sórdido com o qual Graciliano trabalhou não era compatível com fardões assépticos e impecáveis. O povo que falta pelo qual ele escreve é essa "escória" retratada através de seus próprios personagens. Escória que Graciliano conheceu em sua infância, com a qual conviveu na cadeia. Sendo essa a temática de sua literatura, apropriando-se da oralidade dos caboclos isolados nos confins do Brasil para compor sua prosa, Graciliano afasta-se da prolixidade que abomina, do "brilho de ouro falso" que contamina a palavra, da "eloquência tendenciosa", como disse Carpeaux.

Para escrever por um povo, o escritor deve recriar em seu estilo a lingua desse povo. Dai a notória aversão de Graciliano ao academicismo estéril dos 
romances brasileiros do início do século XX, escritos em uma "língua estranha". Mas isso não quer dizer absolutamente recair em um populismo vazio. Por isso, em um polo oposto à repugnância de Graciliano pela linguagem empolada, há também a ojeriza ao modernismo e suas experimentações formais, muitas vezes inócuas (cf. RAMOS, 2014). Essa é a justificativa de sua concepção de escrita direta e sem adornos, embora permeada por regionalismos inspirados na prosódia nordestina.

O movimento da literatura menor de Graciliano é inverso ao dos modernistas e dos regionalistas, seus contemporâneos: em vez de povoar a linguagem culta com "erros", imitações da língua oral, por um caminho inverso, leva os regionalismos e os oralismos para a língua culta (cf. MIRANDA, 2004). Portanto, não devemos também esquecer sua excelência gramatical, a apurada elaboração da forma em seus escritos. Graciliano constrói, num movimento paradoxal, uma lingua própria que se desterritorializa da norma justamente ao se apropriar dela.

Em Infância, podemos entrever o tortuoso caminho do estabelecimento do estilo de Graciliano Ramos. Já identificado por diversos críticos como um romance de formação (cf., por exemplo, MIRANDA, 2004; LEITÃO, 2003), talvez seja no livro de memórias que o questionamento sobre a lingua e a literatura, sempre presente na obra do escritor, atinja o ápice. Mais que uma simples rememoração de uma meninice sofrida, Infância é a narrativa de um aprendizado tanto ético quanto estético, em que o escritor relembra e reconstrói o menino que primeiro descobriu que "nos estreitos limites a que nos coagem a gramática e a lei, ainda nos podemos mexer" (RAMOS, 2011, p. 12).

Encaremos a Linguagem como um dispositivo, no sentido em que o conceito criado por Foucault foi apropriado por Deleuze. Em um pequeno artigo do início da década de 1990, chamado O que é um dispositivo?, Deleuze conceitua dispositivo como uma espécie de novelo informe, composto por atravessamentos com outros dispositivos, caracterizado por linhas que se embaraçam e se bifurcam, possuindo quatro diferentes dimensões: curvas de visibilidade e curvas de enunciação, linhas de poder e linhas de subjetivação. As duas primeiras são concernentes ao regime de tudo que é visto e dito no funcionamento de determinado dispositivo. Pensando em um exemplo de dispositivo concreto, como os hospitais psiquiátricos, podemos visualizar sua arquitetura e seus mecanismos de tratamento, assim como também ouvir o que é dito por meio de seus discursos (no caso, o discurso médico) e de seus programas e relatórios.

$\mathrm{Na}$ linguagem, podemos associar o que é visto ao regime da letra e da lingua escrita, enquanto o que é dito pertence ao âmbito da oralidade. Tais curvas de visibilidade e enunciação se mesclam e se atravessam, agindo de forma diferente em cada dispositivo: podem invadir dimensões politicas, conceber novas posturas estéticas, entrar em comunhão com definições científicas. Às duas primeiras dimensões, mistura-se a terceira, de maior imprevisibilidade e dificil apreensão justamente por ser indizivel e invisivel: é a dimensão das linhas de força. Tais linhas de força compõem-se de poder e saber, são responsáveis por subjugar e capturar, estatizar e formatar. Um dispositivo composto apenas por essas três linhas se tornaria uma estrutura impossivel de ser superada, máquina de controle absoluta da qual nada de novo ou criativo poderia emergir.

A profanação dos dispositivos seria impossivel se não existissem também as linhas de subjetivação. As linhas de subjetivação aparecem quando se dobram as linhas de força, voltando-as para si mesmas, em vez de mantê-las no embate 
sobre outras forças ou sobre as substâncias ou seres. Assim são possíveis os processos - intermináveis - de subjetivação. Mas é preciso não se enganar: as linhas de fuga da subjetivação escapam de um poder e caem em outro, desconstroem um saber para logo em seguida erigir algum outro novo (cf. DELEUZE, 2006). Há, portanto, a necessidade de se deslocar sempre no âmbito dos dispositivos, desterritorializar-se.

O conceito de dispositivo pensado por Deleuze a partir de Foucault é um eco do próprio produto, forjado com Guattari: o complexo e abrangente conceito de agenciamento. Estamos diante de um agenciamento "todas as vezes em que pudermos identificar e descrever o acoplamento de um conjunto de relações materiais e de um regime de signos correspondente" (ZOURABICHVILI, 2003, p. 9). Os agenciamentos são de dois tipos: agenciamentos maquínicos de corpos e agenciamentos coletivos de enunciação. O agenciamento maquínico de corpos é composto pela mistura entre corpos humanos, corpos animais e corpos cósmicos em uma relação de sociedade. Já os agenciamentos coletivos de enunciação dizem respeito aos enunciados, a um regime de signos que regula o uso da língua no socius. Esses agenciamentos coletivos de enunciação não pertencem ao sujeito singular, sua validação só ocorre no âmbito social, já que remetem ao uso compartilhado da linguagem, de símbolos e signos. Correspondendo ao regime de visibilidade e ao regime de enunciação do dispositivo, esses dois pontos do agenciamento são atravessados por outros dois componentes: "lados territoriais ou reterritorializados que o estabilizam e [...] picos de desterritorialização que o arrebatam" (DELEUZE; GUATTARI, 2011, p. 31).

Podemos também associar as características do agenciamento com as linhas de força e as linhas de subjetivação do dispositivo. A desterritorialização é o movimento de abandono do território; a reterritorialização é a construção (ou reconstrução) do território. Na desterritorialização, os agenciamentos são desconstituídos de seu lugar, o que leva à reterritorialização, na qual eles se reconstituem de forma nova: ambos formam o território que, longe de ser um terreno estático, é dinamicamente formado, a partir tanto do deslocamento desterritorializante quanto da reconstrução reterritorializante.

O que direciona os movimentos deterritorializantes, o que estabelece os agenciamentos, é o desejo. Mas o desejo concebido por Deleuze e Guattari nada tem a ver com a ideia de falta, a partir da qual a maioria das teorizações sobre o conceito se formou, desde Platão até Freud. Longe de ser justificado pela existência (real ou imaginária) de um objeto em que seja investido, o desejo, em Deleuze e Guattari, é produção, processo, o próprio móvel da desterritorialização. Sua origem também não remete ao sujeito ou ao mundo interior: o desejo não é uma energia humana que se transporta para o mundo externo. Longe de ser um fato natural, o desejo é uma potência que faz conexões e sinteses sem fim, englobando todo o contexto econômico, social, político e histórico da realidade; máquina retroalimentar, o desejo não tem origem, sua existência se dá justamente nas conexões que faz, nas máquinas desejantes que constrói. Tais máquinas são os agenciamentos.

Deseja-se por agenciamentos. Não se deseja uma coisa isolada, ao que se deseja estão acoplados vários outros materiais e signos que a complementam e ampliam. Deleuze, no Abecedário, dá o exemplo de uma moça que, ao desejar um vestido, deseja ao mesmo tempo uma infinidade de situações, pessoas e afetos relacionados a esse vestido. Como em Proust, em que o desejo por Albertine 
está ligado às paisagens, lugares, vestuários, entre outros exemplos. A vida, longe de ser apenas natureza, é campo de imanência variável do desejo. Há nela uma dimensão criativa, denominada virtual, em que reina o possivel e a produção do novo. Mas também coexiste uma dimensão de controle e estabilidade, chamada atual. Nessa dimensão está a realidade dada e registrada. O desejo age como criador, em um inconformismo com o que já está implantado, um processo produtivo do real que arrasta as intensidades virtuais para a superficie de registro-controle atual e a transmuta (Cf. DELEUZE; GUATTARI, 2010).

Graciliano Ramos tratou como poucos na literatura brasileira do problema do desejo, dos agenciamentos e das desterritorializações. O que mais é Luís da Silva senão uma hecceidade, uma individuação sem sujeito, cujo desejo levou a uma linha de fuga de morte? Quem mais que Paulo Honório manejou e foi subjugado pelos agenciamentos do capital? Fabiano é o desterritorializado por excelência.

Em Infância, espécie de sintese de tudo que a literatura de Graciliano produziu (não no sentido de chave para os romances, como boa parte da crítica enxergou o livro, mas como uma espécie de mapa que aponta pontos de encontro para todas as situações e todos os personagens), o escritor narra os movimentos de uma verdadeira desterritorialização da linguagem, arrancando-a de sua posição dominante, em que as palavras são ordens, gritos e ofensas, e mostra como, reterritorializando-a relativamente na leitura e, mais tarde, de forma absoluta na literatura, devém-se escritor. O percurso, no entanto, é bastante doloroso, deixando cicatrizes que se transmutam em obra literária.

Deleuze e Guattari concebem a linguagem não como uma instituição que visa comunicar ou informar, mas sim como uma emissora de palavras de ordem. "A linguagem não é feita para que se acredite nela, mas para obedecer e fazer obedecer" (DELEUZE; GUATTARI, 2011, p. 12).

Quando fazemos perguntas, pedimos informações, ensinamos, não estamos fazendo nada mais que dando ou seguindo ordens; a informação não provém da linguagem, mas se faz necessária para que possamos compreendê-la em sua dimensão de ordem:

É preciso estar suficientemente informado para não confundir Au feu! (Fogo!) com Au jeu! (Jogo!) [...]. A informação é apenas o mínimo estritamente necessário para a emissão, transmissão e observação das ordens consideradas como comandos (DELEUZE; GUATTARI, 2011, p. 13).

[...]

Chamamos palavras de ordem não uma categoria particular de enunciados explícitos (por exemplo, no imperativo), mas a relação de qualquer palavra ou de qualquer enunciado com pressupostos implícitos, ou seja, como atos de fala que se realizam no enunciado, e que podem se realizar apenas nele. As palavras de ordem não remetem, então, somente aos comandos, mas a todos os atos que estão ligados aos enunciados por uma "obrigação social". Não existe enunciado que não apresente esse vínculo, direta ou indiretamente. Uma pergunta, uma promessa, são palavras de ordem. A linguagem só pode ser definida pelo conjunto das palavras de ordem, pressupostos implícitos ou atos de fala que percorrem uma língua em um dado momento (DELEUZE; GUATTARI, 2011, p. 17).

Para o menino de Infância, o confronto com as palavras de ordem da linguagem se dá desde cedo - junto a um vaso de pitombas escondido atrás de uma 
porta, a mais antiga das lembranças. No meio de uma viagem, quando ainda era criança miúda, a família do menino-protagonista detém-se em uma escola para repousar. Em uma vasta sala, o menino vê que "um velho de barbas longas dominava uma negra mesa, e diversos meninos, em bancos sem encostos, seguravam folhas de papel e esgoelavam-se: - Um $b$ com um $a-b, a$ : $b a$; um $b$ com um $e-b, e: b e "$ (RAMOS, 2002, p. 8).

Essa cena, presenciada pelo menino desde cedo, coloca-o em contato com a figura de autoridade que tantas vezes atravessaria seu caminho mais tarde. Aqui, o poder que emana do velho justifica-se por meio do conhecimento que detém das palavras de ordem. O aprendizado do bê-á-bá assemelha-se à cena de um rito, em que os fiéis repetem a palavra sagrada recitada em língua vernácula por um sacerdote. Tal passagem surge como um eco da narrativa bíblica do decálogo, em que um Deus tirano dita a Moisés sua Lei e depois a inscreve nas pedras. A palavra torna-se mandamento e, inscrita na pedra sagrada, é prova e manifestação do superior poder divino. Assim é muitas vezes o aparecimento da palavra, escrita ou falada, em Infância: um código que evoca e demonstra poder, resultando muitas vezes em violência.

Mas, ao mesmo tempo, a possibilidade de compreensão e translação desse código, a aquisição de informações que permitam responder às palavras de ordem, surge como a própria linha de fuga do meio opressor. A história do Papa-hóstia, cantiga remota que o narrador reconstrói no primeiro capítulo, é uma alegoria que sintetiza o percurso do menino Graciliano em direção à literatura. Um padre pega para criar um menino pobre; tendo um caso com uma mulher, o religioso ensina ao moleque gírias que substituem as palavras referentes as suas safadezas. Desse modo, o padre se autodenominou "papa-hóstia" e deu à mulher a alcunha de Folgazona. Daí a pouco, certos de que não seriam denunciados, a caridade transforma-se em abuso, e o casal passa a maltratar o menino, que se vinga, botando fogo no rabo de um gato e acabando por incendiar a casa do padre.

Tal historieta é objeto de uma interessante reflexão moral por parte do narrador:

Esta obra de arte popular até hoje se conservou inédita, creio eu. Foi uma dificuldade lembrar-me dela, porque a façanha do garoto me envergonhava talvez e precisei extingui-la. Ouvindo a modesta epopeia, com certeza desejei exibir energia e ferocidade. Infelizmente não tenho jeito para a violência. Encolhido e silencioso, aguentando cascudos, limitei-me a aprovar a coragem do menino vingativo. Mais tarde, entrando na vida, continuei a venerar a decisão e o heroísmo, quando isto se grava no papel e os gatos se transformam em papa-ratos. De perto, os indivíduos capazes de amarrar fachos nos rabos dos gatos nunca me causaram admiração. Realmente são espantosos, mas é necessário vê-los a distância, modificados (RAMOS, 2002, p. 16, grifo nosso).

Essa passagem mostra que a linha de fuga percorrida pelo menino em sua formação não o levou a atravessar o limiar da violência: a reterritorialização que vai efetuar é no âmbito do "papel", moldando as palavras, transformando os gatos em papa-ratos, ou seja, fazendo literatura. Trabalhando a linguagem, transformando o código do poder à sua própria maneira, o escritor inverte as linhas de força das palavras de ordem sobre elas mesmas.

Cabe destacar, no entanto, que a literatura não abole a palavra de ordem do âmbito da linguagem, mas se apropria dela de uma forma especial, tendo em 
vista sua dupla face, tanto de emissora da morte, pois, "em toda palavra de ordem, mesmo de um pai para um filho, há uma pequena sentença de morte" (DELEUZE; GUATTARI, 2011, p. 13), quanto de potência revolucionária que torna possivel fazer fugir a linguagem de seu modo repressivo. Ao pensar a língua não como um sistema homogêneo, mas como um agenciamento, composto indiscernivel em que lados territorializados e normativos se deformam em movimentos de desterritorialização e variação contínua, é justamente a palavra de ordem que funciona como seu eixo, tanto podendo estabilizar-se em um elemento reativo e controlador quanto transformar-se em um devir revolucionário e criativo, originando dentro da língua maior sua ramificação menor.

Willy Coelho (2014, p. 159) aponta como a hesitação com que o narrador abre o livro, no primeiro capítulo, "Nuvens", refere-se a uma posição de dúvida, originada no narrador pela "consciência da apropriação da língua como aparato de controle, como dispositivo". Infância é, então, a narrativa do embate do escritor com a palavra de ordem, com a condição perversa da linguagem, mas também a narrativa da inversão desse dispositivo, da desterritorialização em direção à apropriação da lingua para fazer literatura. Mas como funciona esse processo?

Para além da esfera da oralidade, do regime do dito destacado na cantiga do Papa-hóstia, o confronto com a linguagem se dá também, como não poderia deixar de ser, com a palavra impressa, no regime do visto. A mãe tinha por hábito ler folhetins religiosos. Entre esses, um em especial chama a atenção do menino. O tema é o fim do mundo que, de acordo com a publicação, chegaria com a passagem de um cometa, evento próximo. Ao ver a mãe abalada com a profecia, o menino questiona a veracidade das informações: "Não percebendo o mistério das letras, achava difícil que elas se combinassem para narrar a infeliz notícia [...]. Olhei o muro de tijolo, considerei-o indestrutível" (RAMOS, 2002, p. 66). Nesse episódio, o menino começa a questionar o estatuto de verdade absoluta da palavra. Mais tarde, ouvirá do pai que "papel aguenta muita lorota" (RAMOS, 2002, p. 48) e guardará tal afirmação em sua carreira de escritor.

De maneira parecida, o episódio do "inferno" revela para um menino outro interessante aspecto da linguagem, que mais tarde fará parte de seu estilo literário. Para Deleuze e Guattari (2011), a característica primordial da narrativa não é comunicar algo que se viu, mas sim transmitir algo que se ouviu de um outro. Portanto, "a primeira determinação que preenche a linguagem, não é o tropo ou a metáfora, é o discurso indireto" (DELEUZE; GUATTARI, 2011, p. 13). A linguagem funciona então como uma espécie de mapa que transmite palavras de ordem, e não como um decalque emitindo signos informativos.

Em Infância, o menino interroga a mãe a respeito da palavra "inferno", que ele constantemente ouvia, mas não conseguia significar. Diante das explicações insuficientes e paradoxais da mãe, que elaborava relatos fantásticos envolvendo um breu derretido que fustiga eternamente e demônios torturadores que se davam bem nas chamas, o menino questiona: "A senhora esteve lá?"; em resposta, a mulher apela à autoridade eclesiástica, diz que o inferno é assim porque os padres dizem. Mas ele, insatisfeito, torna a perguntar: "Os padres estiveram lá?" (RAMOS, 2002, p. 73).

Aqui o menino intui o discurso indireto, cerne da linguagem, e a incapacidade de encontrar a origem da narrativa, sempre redundante e terceirizada:

Não busquei razões, bastavam-me afirmações. Achava-me disposto a crer, aceitaria os casos extraordinários sem esforço, contanto que não houvesse neles 
muitas incompatibilidades. Reclamava uma testemunha, alguém que tivesse visto diabos chifrudos, almas nadando no breu. Ainda não havia me capacitado de que se descrevem perfeitamente coisas nunca vistas (RAMOS, 2002, p. 73).

Mais tarde, o escritor Graciliano vai utilizar com maestria o recurso do discurso indireto livre em seus romances, principalmente em Vidas Secas ${ }^{1}$. O objetivo é dar primazia aos personagens, constituindo um agenciamento coletivo, em que o autor desaparece por trás da multiplicidade de vozes. Compreendendo o funcionamento das palavras de ordem, Graciliano se engaja em uma desterritorialização que arrasta sua escrita para o âmbito político.

Por meio do aprendizado da leitura, da alfabetização, o menino inverte as linhas de força da Linguagem sobre elas mesmas. O processo, no entanto, é sofrido e custoso. Embora remetendo às primeiras lembranças - os meninos que se esgoelavam repetindo o $b$, $a$ : $b a$ ditado por um velho de barbas longas -, o aprendizado didático das letras começa, de fato, quando o pai lhe persuade a tentar decifrar algumas letras em cartilhas de ABC, "maravilhas" que se tornavam "armas terriveis" (denominação da qual Graciliano se apropriou efetivamente) na mão de quem as dispusesse. Nesse primeiro momento, a aquisição das letras vai mal, pela didática perversa do professor:

Meu pai não tinha vocação para o ensino, mas quis meter-me o alfabeto na cabeça. Resisti, ele teimou - e o resultado foi um desastre. Cedo revelou impaciência e assustou-me. Atirava rápido meia dúzia de letras, ia jogar solo. À tarde pegava um côvado, levava-me para a sala de visitas - e a lição era tempestuosa. Se não visse o côvado, eu ainda poderia dizer qualquer coisa. Vendo-o, calava-me. Um pedaço de madeira, negro, pesado, da largura de quatro dedos (RAMOS, 2002, p. 97).

Associando o aprendizado à punição, o progresso é mínimo, e as letras tornam-se sinônimos de pancadas. Nesses primeiros tempos, as poucas lições úteis de alfabetização são dadas pela irmã natural, Mocinha, que substitui o pai com paciência, e pela primeira professora, D. Maria, "excelente criatura" de "alma infantil" que "não era triste nem alegre, não lisonjeava nem magoava o próximo", "ave maternal" que acolhia "os diferentes instintos de bichos nascidos de ovos diferentes" (RAMOS, 2002, p. 111-114).

Mas a minúscula linha de fuga criada com a ajuda da irmã e da simpática professora é logo obstruída pela imposição da metodologia daquele que se tornaria o símbolo de tudo o que Graciliano abomina na prática da escrita: o Barão de Macaúbas. A rigidez formal, a pomposidade moralista, a retórica que leva a língua à artificialidade: todas essas características são sintetizadas na figura de Abílio César Borges, o tal barão, maior responsável, segundo o narrador, pelos infortúnios que sofreu na difícil aprendizagem da leitura.

Terminado o estudo das cartilhas de $\mathrm{ABC}$ e de um primeiro livro, vencido graças ao auxílio da bondosa professora D. Maria, o menino recebe como tarefa a leitura de mais um livro que, no entanto, causa-lhe repugnância logo de início. $\mathrm{Na}$ contracapa, o retrato de "um tipo de barbas espessas, como as do mestre rural visto anos atrás. Carrancudo, cabeludo. E perverso" (RAMOS, 2002, p. 118). O conteúdo: um apanhado de máximas moralistas emitidas por animais pedantes,

1 A respeito do uso do discurso indireto livre em Graciliano, conferir o estudo de Fábio Freixieiro (1978). 
expressas na linguagem mais sisuda e artificial possível. Assim como o "ter-te-ão" das cartilhas de $\mathrm{ABC}$, a retórica e os aforismos do Barão de Macaúbas são o modelo da mais perversa faceta da linguagem: em seu emaranhado de saber e poder, o objetivo é apartar do bem comum a instituição mais pública de todas, elitizando a linguagem e transformando-a em instrumento para poucos.

A segregação efetuada pela transformação artificial da linguagem é obra de uma politica de organização da realidade baseada na manutenção das posições de poder, usufruindo do saber como principal ferramenta. O menino sente-se incapaz e diminuído tanto diante da brochura presunçosa quanto diante da autoridade detentora de um código de controle indecifrável. É como se a apresentação da língua na pretensa pedagogia do Barão de Macaúbas servisse apenas para demonstrar aos pequenos miseráveis a impossibilidade de deter tal instrumento de poder.

Esse é o maior dos obstáculos encontrados pelo menino em seu aprendizado, mais até que a violência física dos pais, mais que o descaso institucional presente em escolas e professores péssimos: é, na verdade, como se fosse a extensão desses descasos e violências. A forma de superar o obstáculo, em princípio intransponível, o menino aprenderá mais tarde, será com a assistência da literatura.

O Barão de Macaúbas representa o entrave que, uma vez superado, lhe abrirá os caminhos da literatura. Mas, antes de experimentar a leitura dos textos, o menino experimentará a escuridão da cegueira. Sofrendo de oftalmia, doença que acompanhou Graciliano por toda a vida, o menino se vê obrigado a interromper a alfabetização. Mostramos anteriormente como, na descrição dos personagens de Infância, os aspectos físicos (materiais) acoplam-se às maneiras de falar, ler e se expressar (signos) que cada um possui.

Cláudio Leitão, em seu livro Líquido e incerto: memória e exílio em Graciliano Ramos (2003), destaca em Infância a interrelação entre a apreensão auditiva e a apreensão visual, sendo esta o fruto de uma reeducação do olhar perpetrada por aquela. O menino que capta o mundo a sua volta mediante sons, gritos, pancadas, vai dando lugar ao observador, gênese do literato (Cf. LEITÃO, 2003). É pela cegueira que o limiar é rompido; é na escuridão que o semianalfabeto percebe "o valor enorme das palavras" (RAMOS, 2002, p. 131). Temporariamente cego, o menino apura a audição, "os ruídos avultam, os sons adquirem sentido" (RAMOS, 2002 , p. 132). Os ouvidos assumem o lugar dos olhos, cada criatura passa a ser identificada pelo barulho que produz; a atenção para as conversas desenvolve-se, frases são apanhadas e significadas na escuridão. Com a linha da visibilidade obstruída, o menino agarra-se à linha de enunciação, desloca-se por ela no dispositivo da Linguagem.

Mas o confronto com o dispositivo se dá em suas linhas de força. É significativo que a descoberta do valor das palavras se dê entremeada pela audiência das surras que Chico Brabo aplica no menino João. É partindo do corpo que se produz literatura, pois é o corpo a principal peça da máquina do desejo. Graciliano Ramos parte da oftalmia para desembocar na escritura. A violência, que faz parte da formação ética do menino, influi igualmente na formação estética do escritor. Subjugado pelas instituições, o corpo tomado refém pela arbitrariedade da norma, a saída é a escrita. Mas a transição não é abrupta. Subsequente à cegueira e à escola de dona Maria, a família muda-se para Viçosa, no município de Alagoas. O menino é então matriculado 
[...] na escola pública da professora Maria do Ó, mulata fosca, robusta em demasia, uma das criaturas mais vigorosas que já vi. Esse rigor se manifestava em repelões, berros, aos setenta ou oitenta alunos arrumados por todos os cantos (RAMOS, 2002, p. 164).

A pedagogia da nova professora continua a se basear no Barão de Macaúbas e, esquecido em meio à turba de crianças, o avanço do menino em direção à alfabetização estaca, mesmo com o auxílio de uma coleguinha prestativa, Dondom, que acaba por ser espancada pela professora por escrever no caderno do menino as lições que a ele cabiam.

Depois de algum tempo e um novo professor, um "tipo mesquinho, de voz fina, modos ambíguos, e [que] passava os dias alisando o pixaim com uma escova de cabelos duros" (RAMOS, 2002, p. 178), nada muda. O menino continua estacando nas mesmas dificuldades e no mesmo Barão de Macaúbas como pedagogo, mais tarde substituído pelas igualmente autoritárias seletas clássicas. O resultado é que, diz o narrador, "aos nove anos, eu era quase analfabeto" (RAMOS, 2002, p. 187).

A violência institucional paralisa e embota os seres submissos. Mas o desejo não pode ser contido. Linhas de fuga aparecerão para essas crianças: a saída pode se dar através de linhas de vida e criação, ou de morte e destruição. É uma dessas linhas que o menino-protagonista encontra na literatura. O ponto nodal que é a efetiva entrada do menino no mundo da literatura e, consequentemente, da leitura, é narrado no episódio chamado "Os astrônomos", espécie de poética e "lição de hermenêutica" (LEBENSZTAYN; SALLA, 2014, p. 17). Mais uma vez, o pai é figura fundamental.

Ora, uma noite, depois do café, meu pai me mandou buscar um livro que deixara na cabeceira da cama. Novidade, meu velho nunca se dirigia a mim. E eu, engolido o café, beijava-lhe a mão, porque isto era praxe, mergulhava na rede $e$ adormecia. Espantado, entrei no quarto, peguei com repugnância o antipático objeto e voltei à sala de jantar. Aí recebi a ordem para me sentar e abrir o volume. Obedeci engulhado, com a vaga esperança de que uma visita me interrompesse. Ninguém nos visitou naquela noite extraordinária (RAMOS, 2002, p. 188).

Nessa "noite extraordinária", o pai incentiva o menino à leitura e se põe a explicar o que o pequeno acabara de tentar decifrar com dificuldade. O que se abre em seguida é o universo infinito da ficção: crianças perdidas numa floresta, lobos, lenhadores. Tais "criaturas de sonho, incompletas e misteriosas" (RAMOS, 2002, p. 189) revelam então uma capacidade antes desconhecida da linguagem para o menino: a capacidade de narrar, não lorotas moralistas como as dos folhetins religiosos e dos contos do Barão de Macaúbas, mas mundos desconhecidos e, no entanto, tão próximos.

Longe das exigências, das punições, dos conselhos sisudos, a literatura mostra-se um catalisador para o desejo embotado. A personagem que funciona como intermediária é a "excelente" prima Emília. Abalado com a recusa áspera do pai em continuar com as leituras, o menino procura a prima para que decifre para ele o complicado código da linguagem. Então, diz o narrador: "Emília respondeu com uma pergunta que me espantou. Por que não me arriscava a tentar a leitura sozinho?" (RAMOS, 2002, p. 190). E diante das lamúrias do menino, que se diz incapaz, sofredor de fraqueza mental, a prima lhe dá o exemplo dos astrônomos, 
[...] indivíduos que liam no céu, percebiam tudo quanto há no céu. Não no céu onde moram Deus Nosso Senhor e a Virgem Maria. Esse ninguém tinha visto. Mas o outro, o que fica por baixo, o do sol, da lua e das estrelas, os astrônomos conheciam perfeitamente. Ora, se eles enxergavam coisas tão distantes, por que não conseguiria eu adivinhar a página aberta diante dos meus olhos? (RAMOS, 2002, p. 190).

Com o exemplo dos astrônomos, Emília faz pelo menino o que nenhum professor fez: retira o código da lingua de seu estatuto incompreensivel, torna-o decifrável. Não transcendente (não no céu onde moram Deus e Nossa Senhora), mas sim imanente (ligada nem mesmo ao céu de baixo, mas ao mundo): assim é a linguagem. E, sendo "mero" instrumento humano, o menino é capaz de se apropriar dela, sem precisar que nenhum mestre ou autoridade lhe transcreva o que ela diz.

Assim, a lição de imanência dos astrônomos serve ainda para a formação de um projeto literário:

Os astrônomos eram formidáveis. Eu, pobre de mim, não desvendaria os segredos do céu. Preso à terra, sensibilizar-me-ia com histórias tristes, em que há homens perseguidos, mulheres e crianças abandonadas, escuridão e animais ferozes (RAMOS, 2002, p. 191).

O menino apropria-se da linguagem pelo viés do desejo suscitado no contato com a literatura, e isso vai levá-lo a um imenso movimento reterritorializante que o estabelecerá no mundo dos livros e dos literatos. Personagem central dessa passagem é o tabelião Jerônimo Barreto, homem simpático que coloca à disposição do menino sua biblioteca e o apresenta a seus primeiros clássicos literários, como O guarani. O romance de José de Alencar produz um efeito contraditório, pois, ao mesmo tempo que o menino se entretém com índios, fidalgos e aventureiros,

[...] certas expressões me recordaram a seleta e a linguagem de meu pai em lances de entusiasmo. Vi o retrato de José de Alencar, barbado, semelhante ao barão de Macaúbas, e achei notável usarem os dois uma prosa fofa (RAMOS, 2002, p. 213).

Mas, embora o fantasma da língua culta e inacessivel permaneça mesmo em meio às maravilhas da literatura, será esta que lhe proporcionará uma linha de fuga incomensurável, modificando sua relação com o aprendizado e com a tentativa rigorosa e inútil da educação nordestina em concretizá-lo. Na escola,

[...] os meus colegas se afastavam de mim, declamavam as capitais, os rios da Europa [...]. Quando tomei pé na Europa, eles exploravam outras partes do mundo. Surdo às explicações do mestre, alheio aos remoques dos garotos, embrenhava-me na leitura do precioso fascículo, escondido entre as folhas de um atlas. Às vezes procurava na carta os lugares em que o ladrão terrível percorrera. E o mapa crescia, povoava-se, riscava-se de estradas por onde rodavam caleças e diligências (RAMOS, 2002, p. 214).

O que o menino constrói com o auxílio da literatura é um verdadeiro rizoma educacional. Diferentemente dos colegas, presos ao decalque de representações geográficas imposto pelo professor, o menino traça verdadeiras cartografias 
movidas pela ficção, abastecidas pelo desejo. Desejo de conhecer, tão distinto do medo de punição que acompanha os colegas. Tornando-se um agenciamento, o aprendizado formal conecta-se aos sonhos literários, proporcionando uma experiência de exploração do mundo sem que o menino deixe seu espaço no interior do sertão alagoano.

O dificil aprendizado da leitura e da escrita confunde-se com a própria formação do escritor e seu estilo. No longo trajeto do menino pelo mundo da alfabetização, o escritor vai também se constituindo. O estilo que posteriormente será a marca da literatura de Graciliano Ramos reflete a complexa relação com a linguagem na infância. Nas palavras de Leitão (2003, p. 85):

Em sua escrita, o texto autobiográfico de Graciliano Ramos fala da formação, também no curso do consciente aprendizado de artesão, junto com as lições de, simplesmente, ler e escrever [...] E aproxima as transformações púberes do corpo ao começo da leitura e da escrita na vida do escritor.

Os períodos curtos, a aversão aos adjetivos e advérbios, a sintaxe precisa aliada a vocábulos regionais provenientes da lingua falada: tais características do uso particular que Graciliano Ramos faz da linguagem já foram incansavelmente expostas pela crítica em seus detalhes técnicos. Contudo, é necessário tomar o cuidado de não cair na armadilha de ver nesse "estilo seco" uma escrita limitada, de vocabulário restrito, como alerta Leitão (2003).

Segundo Leitão (2003), ao contrário da imagem de escritor minimalista, fixada entre leitores e intérpretes, principalmente por causa de Vidas Secas, Infância apresenta grande riqueza de vocabulário. A verdade é que "Graciliano Ramos, em cada segmento da sua produção literária, fez do léxico um recurso específico, adequado a cada situação dos diversos protagonistas" (LEITÃO, 2003, p. 88). Portanto, se em Vidas Secas o texto é como o protagonista Fabiano, que se comunica na maior parte do tempo com grunhidos e silêncio, em Infância, Graciliano procura mostrar o "valor enorme" que têm as palavras para o menino-protagonista, explicitando no texto como a apreensão de cada uma delas e o que dizem é tão nova e desafiadora quanto o mundo do qual fazem parte.

Fernando Alves Cristóvão, a partir de conceitos de Roman Jakobson, aproximou o estilo de Graciliano à fala dos afásicos. A afasia é uma patologia que causa distúrbios na linguagem, fazendo que o indivíduo perca parte das habilidades cognitivas que produzem a fala. O afásico "não consegue falar ou fala com dificuldades, de forma monótona, pois seus pronunciamentos são curtos, com latência aumentada nas respostas e sem contorno melódico" (DALGALARRONDO, 2008, p. 235).

Para Cristóvão (1977, p. 105), "a redução do diálogo feita pelo monólogo interior, a poupança das partículas na conexão frásica, o enxuto das frases nominais, o uso frequente do estilo indireto livre [...] o estilo seco" de Graciliano corresponde a essa "forma monótona" e "sem contorno melódico" dos afásicos. A escrita de Graciliano Ramos é uma escrita despedaçada, fragmentária, que

[...] caracteriza-se mais pela forma de estruturar a frase e o discurso do que pelo emprego das figuras de estilo baseadas na contiguidade dos sentidos (pars pro parte), e dá especial relevo aos enunciados que dependem do contexto; à tendência para omitir o sujeito, porque ele é subordinante e não subordinado; ao valor dos utensílios gramaticais, que unem as diversas partes do sintagma 
frásico; à sobriedade no uso de sinônimos, heterônimos ou circunlóquios; numa palavra organiza o texto preferindo as relações de contiguidade espacial ou temporal, tal como acontece na correspondente perturbação da linguagem lafasia] (CRISTÓVÃO, 1977, p. 107).

Cristóvão denomina esse estilo de metonímico. Por "estilo metonímico" não devemos entender uma relação com a figura de retórica, e sim uma característica intrinseca da escrita, que procede por uma apreensão fragmentária das imagens e da linguagem, que, segundo ele, está ligada a uma percepção que vai do particular do fragmento ao geral do contexto.

Em Infância, essa propriedade fragmentária do estilo aparece, por exemplo, na descrição dos pais:

Nesse tempo meu pai e minha mãe estavam caracterizados: um homem sério, de testa larga, uma das mais belas testas que já vi, dentes fortes, queixo rijo, fala tremenda; uma senhora enfezada, agressiva, ranzinza, sempre a mexer-se, bossas na cabeça mal protegida por um cabelinho ralo, boca má, olhos maus que em momentos de cólera se inflamavam com um brilho de loucura (RAMOS, 2002, p. 13).

A concepção que o menino-protagonista tem do mundo é constituída por "pedaços". São os dentes, a testa, o queixo, a fala, o cabelo, a boca, os olhos que tornam pai e mãe caracterizados. A partir desses pedaços, todos qualificados (dentes fortes, boca má etc.), forma-se para o menino a imagem dos pais.

Assim como a linguagem, também a organização dos textos de Graciliano é fragmentária: muitos de seus livros - como Infância - são originados de contos avulsos e independentes. Mas, apesar dessa percepção da escrita "despedaçada" do escritor, Cristóvão, ao aproximá-la da metonimia, acaba submetendo-a a uma concepção totalizante, vendo nos fragmentos partes que remeteriam ao todo.

Wander Melo Miranda (2009, p. 86) chama a atenção para essa visão negativa do fragmentário que orienta o estudo do crítico português:

Fernando Cristóvão nega o caráter fragmentário da obra de Graciliano, preferindo defini-la pela metonímia, que lhe daria unidade estrutural e estilistica. Trata-se, evidentemente, de uma visão crítica que considera a fragmentação de modo pejorativo e que parte do pressuposto do sujeito como um todo unitário, para cuja articulação concorreriam, obrigatoriamente, seus diversos desdobramentos textuais.

Afastemo-nos dessa ilusão de totalidade. A escritura de Graciliano Ramos é uma escritura da diferença, do simulacro, da máquina que faz conexões múltiplas e imprevisíveis. O estilo é, para Deleuze, a revelação de uma diferença não individual, mas individualizante: ao mesmo tempo que é particular, o estilo remete a um fora que explica suas ressonâncias universais: "ele [o estilo] nunca é próprio de um ponto de vista, é feito da coexistência, numa mesma frase, de uma série infinita de pontos de vista pelos quais o objeto se desloca, repercute ou se amplifica" (DELEUZE, 2010, p. 158).

Em Infância, o estilo interliga-se ao corpo, tantas vezes violentado. Para fazer frente ao biopoder, criar uma forma de resistência para a vida subjugada, a literatura se volta para o corpo, não apenas o representando, mas o encarnando na linguagem, no próprio corpus textual. O próprio estilo torna-se ferramenta de 
resistência. O menino-protagonista de Infância não conhece uma mãe inteira, indivisivel, e sim "os dedos que nos batiam no cocuruto, dobrados, e tinham a dureza de martelos" (RAMOS, 2002, p. 13); não é a imagem paterna que lhe espanca no episódio do cinturão, e sim "a mão cabeluda [que] prendeu-me, arrastou-me para o meio da sala, a folha de couro fustigou-me as costas" (RAMOS, 2002, p. 31).

Obviamente, isso não significa que o menino não construísse a figura dos pais, mas sim que essas figuras são inapreensiveis a não ser por fragmentos, que são múltiplas e, por isso mesmo, dificeis de compreender. Por vários momentos, o menino mostra perplexidade diante das mudanças repentinas desses "entes dificeis". Propomo-nos então a ver no estilo diferencial de Graciliano uma "linguagem afetiva, intensiva, e não mais uma afecção daquele que fala” (DELEUZE, 2011, p. 138), não a linguagem dos afásicos, mas uma linguagem afásica.

\section{The style of Graciliano Ramos: a DeterRitorialization of language}

Abstract: The present article aims to analyze the style of Graciliano Ramos, exploring, as constituting aspects of the writer's formation, the relation between language apprehension, mastery of reading and the confrontation with the lines of force of the educational process exposed in the memoir book Infância.

Keywords: Graciliano Ramos. Style. Language. Deleuze. Formation.

\section{REFERÊNCIAS}

CARPEAUX, O. M. Visão de Graciliano Ramos. In: BRAYNER, S. (org.). Fortuna crítica. Rio de Janeiro: Civilização Brasileira, 1978.

COELHO, W. C. O incomensurável comum: políticas da escrita em Graciliano Ramos. 2014. 224 f. Tese (Doutorado em Estudos Literários) - Universidade Federal de Minas Gerais, Belo Horizonte, 2014.

CRISTÓVÃO, F. A. Graciliano Ramos: estruturas e valores de um modo de narrar. Rio de Janeiro: Brasília, 1977.

DALGALARRONDO, P. Psicopatologia e semiologia dos transtornos mentais. Porto Alegre: Artes Médicas, 2008.

DELEUZE, G. Two regimes of madness: texts and interviews. New York: Semiotext(e), 2006.

DELEUZE, G. Proust e os signos. Tradução Roberto Machado. Rio de Janeiro: Forense Universitária, 2010.

DEleuzE, G. Critica e clínica. Tradução Peter Pál Pelbart. São Paulo: Editora 34, 2011.

DEleUzE, G.; GUATTARI, F. O que é a Filosofia? Tradução Bento Prado Jr. e Alberto Alonso Muñoz. São Paulo: Editora 34, 2010.

DELEUZE, G.; GUATTARI, F. Mil platôs: capitalismo e esquizofrenia. Tradução Ana Lúcia de Oliveira e Lúcia Cláudia Leão. São Paulo: Editora 34, 2011. v. 2.

DELEUZE, G.; GUATTARI, F. Kafka: por uma literatura menor. Tradução Cíntia Vieira da Silva. Belo Horizonte: Autêntica, 2014. 
FREIXIEIRO, F. O estilo indireto livre em Graciliano Ramos. In: BRAYNER, S. (org.) Fortuna crítica. Rio de Janeiro: Civilização Brasileira, 1978.

LEBENSZTAYN, I.; SALLA, T. M. Conversas com Graciliano Ramos: calado e prosador do inferno. In: LEBENSZTAYN, I.; SALLA, T. M. (org.). Conversas. Rio de Janeiro; São Paulo: Record, 2014.

LEITÃO, C. Líquido e incerto: memória e exílio em Graciliano Ramos. Niterói: Editora UFF, 2003.

MIRANDA, W. M. Corpos escritos. São Paulo: Edusp, 2009.

MIRANDA, W. M. Graciliano Ramos. São Paulo: Publifolha, 2004. (Folha explica). PEREIRA, M. Homenagem a Graciliano. In: BRAYNER, S. (org.). Fortuna critica. Rio de Janeiro: Civilização Brasileira, 1978.

RAMOS, G. Cartas. Rio de Janeiro: Record, 1994.

RAMOS, G. Infância. Rio de Janeiro: Record, 2002.

RAMOS, G. Memórias do cárcere. Rio de Janeiro: Record, 2011.

RAMOS, G. Conversas. Organização Ieda Lebensztayn e Thiago Mio Salla. Rio de Janeiro; São Paulo: Record, 2014.

ZOURABICHVILI, F. O vocabulário de Deleuze. Tradução André Telles. Rio de Janeiro: Relume Dumará, 2003. 